\title{
Earnings persistence of Nigerian listed banks
}

\author{
Segun Abogun ${ }^{1}$, Taiwo Azeez Olaniyi ${ }^{2}$, Muftau Adeniyi Ijaiya ${ }^{3}$, Temitope Olamide Fagbemi ${ }^{4 *}$ \\ ${ }^{1,2,4}$ Department of Accounting, University of Ilorin, Kwara, Nigeria \\ ${ }^{3}$ Department of Finance, University of Ilorin, Kwara, Nigeria \\ ${ }^{*}$ Corresponding author: olamidefag@yahoo.com
}

\begin{abstract}
Banks report huge profits yearly yet some of these banks were reported to lack capital adequacy and some were reported to be close to being insolvent. Therefore, it is important to determine whether or not the profits reported by these banks are persistent. As a result, the main objective of this study is to examine the persistence of earnings of Nigerian listed banks. The explanatory research design was adopted and data were gathered from the secondary source, specifically from the financial statements of Nigerian quoted banks. The entire fifteen (15) quoted deposit money banks which constitute the population of the study was examined over a period of eleven (11) years spanning 2005 to 2015. In this study, the Generalized Method of Moments (GMM) dynamic panel estimation technique was employed. The study found that the earnings of the Nigerian listed banks are less persistent, that is, less sustainable. It is therefore recommended that investors should exercise caution by paying less attention to reported earnings. Instead, effort should be made to determine the persistent level of earnings to avoid wrong investment decisions.
\end{abstract}

Keywords: Persistence, Earnings, Banks, Investment Decision, GMM JEL Classification Code: G21 DOI: $10.20885 /$ jsb.vol24.iss2.art6

\section{Introduction}

The efficient allocation of resources among competing users of funds is one important objective of the Stock Markets while the quantum of funds accessed by firms from the capital market depends largely amongst other things on their performances (financial or otherwise). This is because a rational investor would be willing to invest his/her funds in firms that maximize wealth. Therefore, in order to make this investment decision, they need the information that would enable them to assess the underlying risk associated with investment opportunities. Investors also need information that would enable them to ascertain the amount, timing, and uncertainty of future cash flows on their investments.

Furthermore, the information helps them to assess the present and the future performance of firms. This performance is assessed from different points of view, depending on the decision at hand; which includes equity valuation, liquidity position, corporate social responsibility, profitability level, and financial position amongst others. From the valuation perspective, profit constitutes an important input variable in equity valuation models (Kothari, 2001; Dechow, Ge, \& Schrand, 2010).

However, as important as earnings are input variables in equity valuation models, investors must take a critical look at the reported earnings beyond the face value. Investors may need to assess the persistence of reported earnings in making their investment decisions amongst other things instead of fixating reported earnings (Sloan, 1996); otherwise, they may be misled into making a wrong investment decision. The issue of assessing the persistence of firms' reported earnings is very crucial especially in situations where firms reported huge profits and shortly after go into extinction. Some other firms may not go into extinction but could hardly meet up with obligations of paying workers' salaries regularly, repaying loan and interest to lenders, and settling of trade creditors which may result in a take-over bid by a healthier company. In particular, some banks which were viewed as successful having reported brilliant performances in prior periods were 
shortly discovered to be unhealthy resulting in liquidation or take-over by healthier banks. Therefore, there is a dare need to give a closer look at reported profits by examining the persistence (sustainability) of such profits rather than naïve assessment of the billions of naira of profits reported in the financial statements of banks. Undoubtedly, most deposit money banks in Nigeria usually report profits in billions of naira e.g in 2015 financial year-end, the United Bank for Africa (UBA) plc reported a profit close to forty-eight billion naira ( $\$ 47,642,000,000)$ (UBA published annual reports and accounts, 2015); Wema Bank Nigeria plc recorded over two billion naira ( 2,300,000,000) profit for the year 2015 (Ogunwale, 2016); Eco-Bank Nigeria plc also reported over two billion naira ( 21,025,000,000) in 2015 ("Eco bank records 68\% decline in PAT," 2016); Union Bank of Nigeria plc reported a profit of about sixteen billion naira (15,700,000,000) for 2016 financial year ("Union bank records marginal profit rise," 2017) just to mention few. However, despite the huge reported profits year in year out by these banks, the stress test which is also referred to as liquidity ratio and capital adequacy test conducted by the central banks of Nigeria in 2016 revealed that no fewer than seven (7) banks failed the capital adequacy test while two (2) banks were reported to be close to being insolvent, that is, failed the liquidity ratio test (Oyetunji, 2016). Furthermore, a bank reported a profit after tax of over eighteen billion naira ( 18,717,000,000) in the previous year but reported a loss of over forty billion naira ( 40,726,000,000) in the immediately following year (This Day newspaper, August 7, 2016). The question is: how persistent/sustainable is the profit reported by banks in Nigeria?

Earnings persistence is one of the measures of earnings quality; other measures include earnings predictability, accrual quality, smoothness, value relevance, timeliness, conservatism, and earnings response coefficient (Francis, Lafond, Olsson \& Schipper, 2004; Dechow et al., 2010; Xie, 2015; Ruch \& Taylor, 2015). Persistent earnings can be described as earnings that re-occur beyond the present time into the future of firms; mostly connected with the core operating activities of firms, management efficiency, and firms' fundamental characteristics. Therefore, investors who fixate on the absolute value of reported earnings do not consider the permanent component of earnings which is referred to as earnings persistence (Coelho, Aguiar \& Lopes, 2011).

While many studies such as Filip and Raffournier (2010); Oyerinde (2011); Gjerde, Knivsfla and Saettem (2011); Uwalomwa, Olowe, and Agu (2012); Enahoro and Jayeoba (2013); Olugbenga and Atanda (2014); Modugu and Ohonba (2014); Elshandidy (2014); Baffa, Mohammed and Abdulkadri (2014); Ejuvbekpokpo and Edesiri (2014); Foster (2015); Omokhudu and Ibadin (2015); Felix and Rebecca (2015); Onalo, Lizam, Kaseri and Usman (2015); Umoren and Enang (2015); and Abubakar (2012) have assessed other measures of earnings quality, not much attention have been paid to the persistence of earnings in Nigeria; hence this study attempts to fill this gap. Furthermore, the bases for choosing the banking industry are two. First, the Nigerian banking sector constitutes a large part of the total market capitalization of the Nigerian Stock Exchange (Nigerian Stock Exchange Facts Book, 2016); and as such it is believed that studying the banking sector could provide a fair overview of the Nigerian Stock Market behavior. The second reason is based on the fact that the Nigerian banking sector is highly regulated such that combining it with firms in other sectors with low regulations may distort the results of the study. Therefore the purpose of this study is to examine the persistence of earnings of Nigerian listed banks. In order to achieve this objective, the study examined whether or not the current earnings contains history of itself by regressing the value of current earnings on its lagged values.

\section{Literature Review}

The issue raised in this study concerns the persistence of earnings which consequently serves as input variables into the equity valuation model. The quality of earnings for valuation purposes is largely determined by the persistence/sustainability of such earnings. However, investors sometimes fail to determine the persistence level of firms' earnings; instead they just 'fixate' on earnings, which may lead to over/underpricing of security. Therefore, it becomes imperative to examine the 
persistence of earnings of Nigerian firms, the banking sector in particular to avoid mispricing of stocks; in order to do this the random walk theory is used.

The random walk theory which is also known as the martingale or sub-martingale process holds that in an efficient market, the future price of a security cannot be predicted using the past history of security prices (past and current). It means that the successive change in the price of a security is unpredictable using the history of itself (Fama, 1990 cited in Pandey, 2004; Obayagbona \& Igbinosa, 2014). This is because the security price movement is always trending, and as a result, any effort to make a forecast using a trending series (unpredictable behavior) may be a futile exercise. This hypothesis assumes that the market is informational efficient such that all publicly available information is instantaneously impounded in the security price. The implication is that no market participants can make an abnormal profit on a consistent basis using the information set contained in past security prices.The theory, therefore, posits that in a purely random walk process, the best prediction of future price of the security is the price of the security today (martingale process). On the other hand, in a sub-martingale process, the price of security tomorrow equals the price of security today plus a drift, that is, an increase or decrease (Gujarati \&Porter, 2009). Similar to security price behavior, the literature reveals that the time-series properties of firms' earnings follow the random walk hypothesis such that successive changes in firms' earnings are independent and unpredictable. It also means, the value of earnings today is equal to its immediate past value plus a random shock. It is this random shock that makes it difficult if not impossible to predict earnings value based on its value today. The random walk model, when it is stated in a regression form can be applied to examine earnings persistence. This is so because in a random walk model with drift for instance, current earning is equal to previous earnings (lagged value) plus a constant intercept, plus a random shock; hence, it was applied in this study. Therefore, in the context of earnings persistence, this study hypothesized that: the current value of earnings is explained by its previous value. It is also on this basis that the earnings persistence model which is a regression of today's earnings on yesterday's earnings, constant intercept, and a random shock was specified in section three of this study.

The quality of earnings from the valuation perspective is shown by the association between earnings and market values such as security price and return (Dechow et al., 2010). It is also shown by how earnings yield better as input variables into the equity valuation model. To this end, pieces of evidence from past studies show that earnings are of good quality (Bender \& Nielsen 2013; Akileng 2013; Oyerogba, 2014; Ferrero, 2014; Folsom, Hribar, Mergenthaler, \& Peterson 2016). It has been documented in the literature that conservatism has both costs and benefits to the users of financial statements. Users may be broadly classified into equity users (referred to as valuation perspective), bond and management compensation (usually referred to as contracting perspective).

In the use of earnings for assessing the market value of equity, it has been documented that accounting conservatism reduces earnings persistence and consequently the ability of earnings to influence changes in share price (Bandyopadhyay, Chen, Huang \& Jha 2010; Ismail \&Eibolok, 2011; Chen, Folsom, Paek \&Sami 2014). This is because accounting conservatism reduces downward the value of net assets in response to bad news (both actual and anticipated) but does not increase net assets in response to good news except it is verified to have been realized. This downward bias in the book value of equity explains partly the difference between it and the market value of equity. However, it is claimed by some writers that it is helpful to disaggregate accounting conservatism into conditional conservatism and unconditional conservatism (Chen, Miao \& Shevlin, 2015). It is reported that conditional conservatism is negatively associated with earning persistence and consequently equity pricing (Kim \& Kross, 2005; Bandyopadhyay et al., 2010). It is further reported that the impact of unconditional conservatism on earnings persistence is not negative as much as conditional conservatism (Chen, Folsom, Paek \& Sami, 2014). On the other hand, in contracting setting, accounting conservatism has been found useful for alleviating asymmetric pay-offs between contracting parties. One of the advantages of accounting conservatism in a contracting setting is 
that it forces management to embark on profitable projects that maximize owners' wealth. Unlike the shreds of evidence showing the failure of earnings to predict future earnings, it has been documented that the ability of earnings to predict future cash flows is increasing (Bandyopadhyay et al., 2010).

Furthermore, evidence from Sloan (1996); Richardson et al. (2005); Dechow \&Ge (2006) shows that accrual accounting contributes to the observed decline in earnings persistence such that accrual component of earnings is less persistence of earnings than the persistence of cash flows The studies by Sloan (1996); Richardson et al. (2005); Oei, Ramsay \& Mather, 2008; Boubakri, (2012); Chen \&Shane (2014) further reveal that accrual leads to low persistence of earnings but does not lead to low persistence of cash flows component of earnings. It is reported that the ability of cash flows to predict future earnings is higher than accrual earnings. Furthermore, Kim and Kross (2005) document that the ability of earnings to predict future cash flows increased and not decreased for a period of 28 years. Others also document that current year cash flows sufficiently explain future cash flows at least by a year ahead (Dechow, Richardson \&Sloan 2008; Artikis \& Papanastasopoulos, 2016). However, Dechow and Dichev (2002); Park \& Shin (2015) provide contrary evidence. Their study reveals the importance of determining accrual quality before relating it to earnings persistence. They document that accrual quality is positively related to earnings persistence. Nevertheless, Sloan (1996) has attributed the difference between the persistence of earnings and cash flows to the estimation error in accruals. Other studies provide empirical evidence over other factors affecting earnings persistence such as the adoption of international financial reporting standards, Earnings management, Gender of top executives, and readability of earnings report (Richardson, Sloam, Soliman \&Tuna, 2005; Ye, Zhang, \&Rezaee, 2010; Doukakis, 2010; Sun, Cahan \& Emanuel, 2011; Atwood, Drake, Myers \& Myers 2011; Papanastasopoulos, 2015).

From the forgoing, it is clear that the empirical evidence on earnings persistence and predictability is mixed and inconclusive. While some studies reported a positive association between future year earnings and the current year earnings, and consequently stock price (Giner \&Riverte, 2003; Tonks, 2007; Bandi, 2012; Pimentel \& De Aguiar, 2016; Moienadin \&Tabatabaenasab, 2014; Kothari, Lewellen \& Warner, 2006; Oluoch \&Gichaiya 2015; Folsom, Hribar, Mergenthaler, \& Peterson 2016); others reported a negative association (Bearver, Lamber \&Morse, 1980; Giner, \&Riverte, 2003; Dichev \&Tang, 2008).

Finally, the concern raised by Kim and Kross (2005) over the observed decline in the relationship between earnings and market despite the fact that there are evidence strong association between earnings and future cash flows demands further empirical research. Future research may also attempt to provide further reason for the difference between earnings persistence and cash flows persistence.

\section{Methods}

The random walk theory (without drift) establishes a formal link between current year earnings and previous year earnings (Ball \& Watts, 1972; Watts \& Leftwich, 1977; Gujartai \& Porter, 2009; Nwidobie, 2014) as:

$\mathrm{Y}_{\mathrm{t}}=\mathrm{Y}_{\mathrm{t}-1}+\mathrm{e}_{\mathrm{t}}$

Where: $\mathrm{Y}_{\mathrm{t}}$ represents the current value of a random variable, $\mathrm{Y}_{\mathrm{t}-1}$ represents the lag value of the same random variable, and $e_{t}$ is the error term. In the accounting literature, the random walk theory has been used to study the time-series behavior of annual earnings.

Therefore, following the works of Freeman et al. (1982); Sloan (1996); Francis et al. (2004); Richardson et al. (2005); Boubakri (2012); Park \& Shin (2015); Artikis \& Papanastasopuolos (2016), this study specifies earnings persistence model as:

$\mathrm{EPS}_{\mathrm{it}}=\lambda_{0}+\lambda_{1} \mathrm{EPS}_{\mathrm{it}-1}+\gamma_{\mathrm{it}}$ 
where: EPS $_{\text {it }}$ represents current-year earnings per share for all banks included in the study over the period covered (denoted by it), EPS $\mathrm{it}-1_{1}$ is the lag value of earnings per share for all the banks included in the study over the period covered, $\lambda_{0}, \lambda_{1}$ are the persistence parameters, and $\gamma_{\text {it }}$ is a oneway error component. Where $\lambda_{1}$ is positive and statistically significant then it shows that there is evidence of earnings persistence but if otherwise, there is no evidence of earnings persistence. The choice of earning per share (EPS) rather using other measures is based on the fact that EPS is a premier source of information to investors and as such, they look out for it. For instance, Sloan (1996) claimed that investors fixate on earnings ordinarily. This is because earnings provide a quick basis for assessing companies' performance. It also guides investors on what dividend they are likely to get given the number of shares held and in the same vein, how the market would price their investment.

In order to examine how current-year earnings are influenced by previous year earnings using regression analysis (a measure of earnings persistence), the explanatory research design was adopted. Furthermore, this study examines the earnings persistence of all the fifteen (15) Nigerian listed banks over the period of eleven (11) years; hence this study is a census study without any recourse to sampling.

The data source employed in this study is the secondary source of data gathering. The variables of this study are basically current year profit and the previous year profit. Therefore, the earnings information was sourced from the income statements of the quoted banks. Consequently, the profit on ordinary activities after tax before extraordinary items was used. This because extraordinary items are non-recurring items/activities of firm, and they do not constitute the ordinary activities of the firms. The earnings per share were used instead of the aggregate value to harmonize differences in values of earnings across firms. It is calculated as profit on ordinary activities after tax but before extra-ordinary items (it is now referred to as profit for the year) minus preference share dividends divided by units of ordinary shares issued ranking for dividend (profit for the yearpreference dividend/ordinary shares issued ranking for dividend).

The data gathered was a panel data since it combined both cross-sectional units and time series together and as such, panel regression technique was employed. The type of panel regression model specified in this study is a dynamic panel regression models. This is because the model included the lag of the dependent variable as the independent variable. As contained in Francis et al. (2004), such models are usually referred to as the Auto-Regressive model of order one, AR (1). It is established in the literature that the time-series behavior of the annual earnings of corporate entities follows the random walk process and as such, it is a non-stationary series. In the case of a random walk without a drift, even though their mean is zero, the variance is not constant over time; making the ordinary least square method of estimation unsuitable for this work. The inclusion of lagged dependent variable as independent variable renders the pooled ordinary least square method, fixed effect method, and random effect method inappropriate estimation techniques for this study. Such inclusion of lagged dependent variable as the independent variable makes the static panel estimators biased, inconsistent or both. In other to overcome the weaknesses of the static panel estimators in estimating the dynamic panel regression model such as specified in this study, the Arellano and Bond-Generalized Method of Moments (GMM) estimation technique were employed. The Arellano and Bond-Generalized Method of Moments (GMM) is a first difference GMM. This estimator has some characteristics that put it at advantage over static panel estimators. Firstly, it is suitable for a panel data set that has small-time, $T$ dimension but relatively large cross-sectional units (Arellano \& Bond, 1991). Secondly, it is capable of estimating a panel regression model that includes the lagged dependent variable as an independent variable. Thirdly, it provides a first difference of the model and as a result, the correlation between the lagged value of the dependent variable and the individual effect is removed. Unlike the fixed effect and the random effect, it further eliminates the correlation between lagged dependent variable contained in the first difference of the dependent 
variable and lagged value of the error term contained in the first difference of the error term (Naveed, Prean \& Rabas, 2011).

\section{Results and Discussion}

In order to provide an answer to the research question raised in this study, the study hypothesized that previous year earnings do not positively influence current year earnings. In determining the persistence of earnings, the coefficient of previous year earnings is expected to be positive and significant (Sloan, 1996; Francis et al., 2004; Richardson et al., 2005; Kim \& Kross 2005; Lawrence, Sloan \& Sun, 2014). In addition, Francis et al., (2004) state the coefficient value that is close to 1 mean highly persistent but the coefficient value that is close to 0 implies low persistence. A key assumption of the Arellano and Bond (1991) estimator is that the higher-order autocorrelation is absent. As contained in Table 1, the diagnostic test showed that the second-order autocorrelation is absent and also the result of the Sargan test shows that the instruments used in the analysis are valid.

Table 1. Diagnostic Tests (Sargan and Autocorrelation)

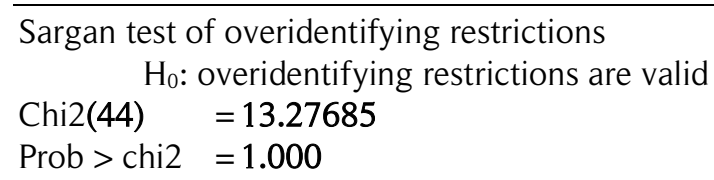

Arellano- Bond test for zero autocorrelation in first- differenced errors $\mathrm{H}_{0}$ : No Autocorrelation

\begin{tabular}{lll}
\hline Order & Z & Prob> z \\
\hline 1 & -.99209 & 0.3212 \\
2 & .59219 & 0.5537 \\
\hline
\end{tabular}

Source: Authors' Compilation

The regression results as contained in Table 2 reveal that the coefficient of the previous year earnings $\left(E P S_{L 1}\right)$ is both negative and significant at $1 \%$ significance level. The magnitude of the coefficient which measures the marginal effect is -0.4103329 with a standard error of 0.0175545 and a p-value of 0.000 . The statistical meaning of this result is that the independent variable (lagged value of earnings) significantly explained the variation in the dependent variable (current value of earnings). The coefficient of the independent variable is statistically significant because its $p$-value of 0.000 is less than 0.01 . This result confirmed the theoretical foundation (random walk model) and hypothesis of this study since the lagged value of earnings statistically explained the current value of earnings. The result also confirmed the findings of previous studies such as Pimentel and DeAguiar (2016); Moienadin and Tabatabaenasab (2014); Kothari, Lewellen and Warner (2006); Oluoch and Gichaiya (2015). However, the striking difference between the findings of this study and the previous studies is that the sign of the coefficient as reported in this study is negative and it is not close to one (1). The meaning adduced to such result is that the persistence of earnings of Nigerian listed banks is low. The observed difference in the findings of this study and that of the developed economies can be attributed to the fact that Nigeria economy is a developing economy where scale of operation is relatively low. It could also be due to the fact that reported profits of Nigerian listed banks are sometimes obtained from sources other than their ordinary activities. Finally, the model is well fitted given the Wald Statistics value of 546.38 and a p-value of 0.0000 which means the independent variable included in the model was relevant in explaining the dependent variable. 
Table 2. Dynamic Panel Regression Results

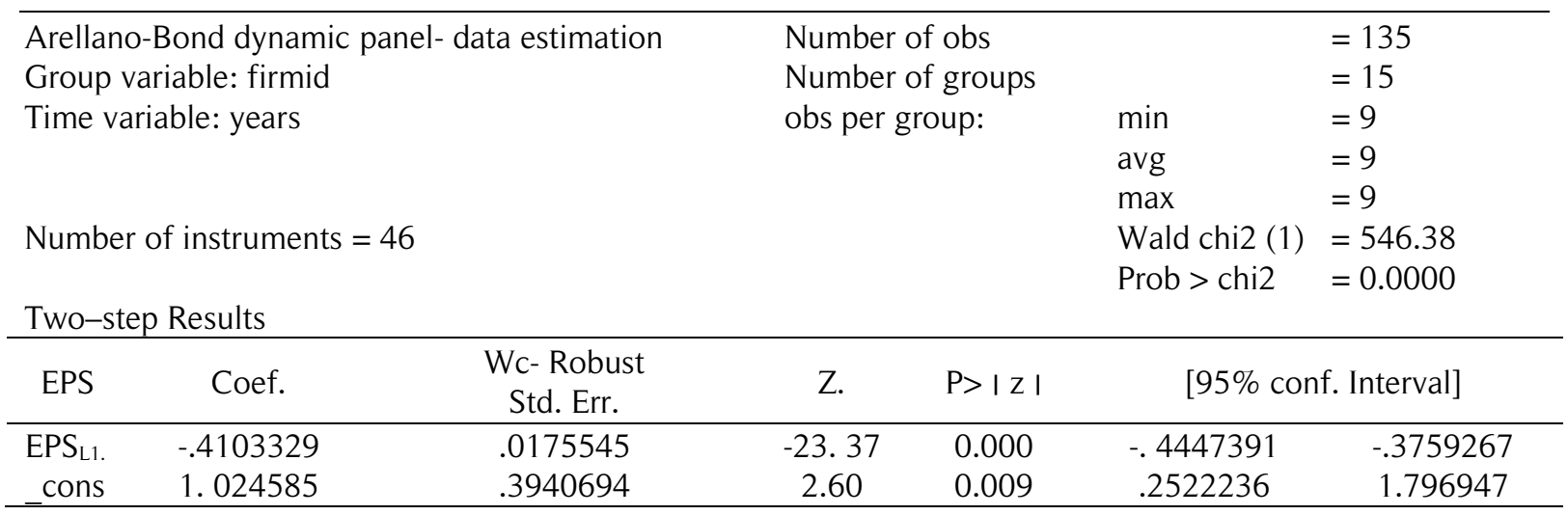

Source: Authors' Compilation

In summary, the key finding of this study is that the earnings of Nigerian listed banks are less persistent. The persistence of earnings in this sense is conceived to mean sustainability of earnings. Earnings that are not persistent are usually referred to as transitory earnings or temporal earnings and their reoccurrences are expected to last for a short period of time. It is the permanent component of earnings that are persistent but not the transitory component. Rational investors place high premium over permanent earnings. The consequence of reporting sustainable earnings is that investors would allocate funds to such firms and possibly withdraw their funds from firms that could not sustain earnings. It is important to note that firms may report huge profits at the end of the financial year meanwhile, the profits are not sustainable. In this case, it is possible that large portion of reported earnings of Nigerian listed banks came from extra-ordinary incomes which by nature are transitory. It is also possible that the low persistence is the effect of applying accounting conservatism in preparing the earnings. The principle of conservatism as practiced in Nigeria anticipates and recognizes all possible losses but exercises caution in recognizing probable gains. This practice is capable of causing distortion in reported earnings.

\section{Conclusion}

This study examines the persistence of earnings of the Nigerian banking sector; and in order to this, current year earnings were regressed on the lagged values earnings using the Arellano and Bond's Generalized Method of Moment estimation technique.

The study found that the current year earnings of these banks are negatively correlated with previous year earnings. The meaning of such a finding is that the earnings of the Nigerian quoted banks are less persistent. It is therefore concluded that the earnings of the Nigerian quoted banks are less persistent.

Based on the conclusion reached in this study, it is recommended that market participants especially the investors should ensure to determine the persistence of earnings by decomposing aggregate earnings into cash components and accrual components before pricing the securities of firms rather than fixating on aggregate reported earnings. By so doing, the incidence of security mispricing by market participants would be reduced; and as a result, investors would be well informed to make a rational investment decision. It is also recommended that the government of Nigeria should revitalize the economy through diversification so as to scale up the operation of banks in Nigeria. Finally, it is recommended for future researchers to eliminate incomes outside ordinary activities from the total profit before examining earnings persistence of Nigerian firms.

\section{References}


Abubakar, S. (2012).Value relevance of accounting information of listed new economy firms in Nigeria: An empirical investigation using ohlson model. Retrieved from http://www.docfoc.com/value-relevance-of-accounting-information-of-listed-new-economyfirms-in-nigeria-an-empirical-investigation-using-ohlson-model.

Akileng, G. (2013). Market valuation of accounting earnings: Review of evidence andmethodological Issues. International Journal of Economics, Finance and Management, 2(6), 421-429.

Arellano, M. \& Bond, S. (1991). Some tests of specification for panel data: Monte Carlo evidence and an application to employment equations. Review of Economic Studies, 58, 277-297.

Artikis, P. G., \& Papanastasopoulos, G. A. (2016). Implications of the cash component of earnings for earnings persistence and stock returns. The British Accounting Review, 48(2), 117-133.

Atwood, T. J., Drake, M. S., Myers, J. N., \&Myers, L.A. (2011). Do earnings reported under IFRS tell us more about future earnings and cash flows? J. Account. Public Policy, 30, 103-121

Baffa, A. M., Mohammed, R. A., \& Abdulkadir, R. I. (2014). The value relevance of IFRS adoption: evidence from listed banks in Nigeria. Ilorin Journal of Accounting, I(2), 163-181.

Ball, R. \& Watts, R. (1972). Some time series properties of accounting income. The Journal of Finance, 27, 663-681.

Bandi (2012). Finance perspective versus accounting perspective: The case of earnings persistence in Indonesia. International Journal of Economics and Finance, 4(9), 191-199.

Bandyopadhyay, S. P., Chen, C., Huang, A. G., \& Jha, R. (2010). Accounting Conservatism and the Temporal Trends in Current Earnings' Ability to Predict Future Cash Flows versus Future Earnings: Evidence on the Trade-off between Relevance and Reliability. Contemporary Accounting Research, 27(2), 413-460.

Beaver, W., Lambert, R., \&Morse, D. (1980). The information content of security prices. Journal of Accounting and Economics, 2, 3-28.

Bender, J. \& Nielsen, F. (2013). Earnings quality revisited. The Journal of Portfolio Management, 6979.

Boubakri, F. (2012). The relationship between accruals anomaly in the Canadian context. International Journal of economics and Finance, 4(6), 51-62.

Chen, J. Z. \& Shane, P. (2014). Changes in cash: Persistence and pricing implications. Journal of Accounting Research, 52(3), 599-634.

Chen, L. H., Folsom, D. M., Paek, W., \& Sami, H. (2014). Accounting conservatism, earning persistence, and pricing multiples on earnings. Accounting Horizon, 28(2), 233-260.

Chen, S., Miao, B., \& Shevlin, T. (2015). A new measure of disclosure quality: The level of disaggregation of accounting data in annual reports. Journal of Accounting Research, 53(5), 1017-1054.

Coelho,A. C., Aguiar, A. B. D., \& Lopes, A. B. (2011). Relationship between abnormal earnings persistence, industry structure, and market share in Brazilian public firms. BAR-Brazilian Administration Review, 8(1), 48-67.

Dechow, P. M. \&Ge, W. (2006). The persistence of earnings and cashflow and role of special items: Implications for the accrual anomaly. Review of Accounting Studies, 253-296. 
Dechow, P., Ge, W., Schrand, C. (2010). Understanding earnings quality: A review of the proxies, their determinants and their consequences. Journal of Accounting and Economics, 50, 344401.

Dechow, P. M. \& Dichev, I. D. (2002). The quality of accruals and earnings: The role of accrual estimation errors. The Accounting Review, 77, 35-59.

Dechow, P. M., Richardson, S. A., \& Sloan, R. G. (2008). The persistence and pricing of the cash component of earnings. Journal of Accounting Research, 46(3), 538-566.

Dichev, I. D., \& Tang, V. W. (2008). Matching and the changing properties of accounting earnings over the last 40 years. The Accounting Review, 83(6), 1425-1460.

Doukakis, L. C. (2010). The persistence of earnings and earnings components after the adoption of IFRS. Managerial Finance, 36(11), 969-980.

Eco bank records 68\% decline in PAT to \#21.2 billion. (2016, April 14). This Day newspaper. Retrieved on $12^{\text {th }} \quad$ April, 2017 from https://www.thisdaylive.com/index.php/2016/04/14/ecobank-records-68-decline-in-profitafter-tax-to-n21-2-billion/

Ejuvbekpokpo, A. S., \& Edesiri, G. O. (2014). Determinants of stock price movement in Nigeria: Evidence from the Nigerian stock exchange. Journal of Economics and Sustainable Development, 5(3), 1-7.

Elshandidy, T. (2014). Value relevance of accounting information: Evidence from an emerging market. Advances in Accounting, incorporating Advances in International Accounting, 30(1), 176-186.

Enahoro, J., \& Jayeoba, J. (2013). Value measurement and disclosures in fair value Accounting. Asian Economic and Financial Review, 3(9), 1170-1179

Felix, U. O., \& Rebecca, U. O. (2015). Theory of conservatism and value relevance of accounting information. Accounting and Marketing, 4(1), 1-8.

Ferrero, J. M. (2014). Consequences of Financial reporting quality on corporate performance. Evidence at the international level. Estudios de Economia, 41(1), 49-88

Filip, A., \& Raffournier, B. (2010). The value relevance of earnings in a transition economy: the case of Romania. The International Journal of Accounting, 45, 77-103.

Folsom, D., Hribar, P., Mergenthaler, R. D., \& Peterson, K. (2016). Principles-based standards and earnings attributes. Management Science.

Foster, G. (2015). Stock market reactions to estimates of earnings per share by company officials. Journal of Accounting Research, 11(1), 25-37.

Francis, J., Lafond, R., Olsson, P., \& Schipper, K. (2004). Costs of equity and earnings attributes. The Accounting Review,79 (4), 967-1010.

Freeman, R. N., Ohlson, J. A., Penman, S. H. (1982). Book rate-of-return and prediction of earnings changes: An empirical investigation. Journal of Accounting Research, 20(2), 639-653.

Giner, B. \&Riverte, C. (2003). The predictive ability of financial information for future earnings: A European perspective. Revista Espanola de Financiacion Y contabilidad, 32(115), 8-43

Gjerde, O., Knivsfla, K., \& Saettem, F. (2011). The value relevance of financial reporting in Norway 1965-2004. Scandinavian Journal of Management, 27, 113-128.

Gujarati, D. N. \&Porter, D. C. (2009). Basic econometrics ( $5^{\text {th }}$ ed.). New York: McGraw Hills 
Ismail, T. H. \&Elbolok, R. M. (2011). Do conditional and unconditional conservatism impact earnings quality and stock prices in Egypt? Research Journal of Finance and Accounting, 2(12), 7-21.

Kim, M. \& Kross, W. (2005). The ability of earnings to predict future operating cash flows has been increasing-not decreasing. Journal of Accounting Research, 43(5), 753-780.

Kothari, S. P. (2001). Capital market research in accounting. Journal of Accounting and Economics, 31 (2001), 105-231.

Kothari, S. P., Lewellen, J., Warner, J. B. (2006). Stock returns, aggregate earnings surprises and behavioral finance. Journal of Financial Economics, 79 (2006), 537-568.

Lawrence, A., Sloan, R., \&Sun, Y. (2014). Why are losses less persistent than profit? Curtailment versus conservatism. Accounting Workshop by Accounting Research Center, Chicago.

Modugu, K. P., \& Ohonba, N. (2014). Impact of price level changes on financial accounting measurement. Centrepoint Journal (Humanities Edition), 17(1), 33-34.

Moienadin, M. \& Tabatabaenasab, Z. (2014). Examining the earnings persistence and its components in explaining the future profitability. Interdisciplinary Journal of Contemporary Research in Business, 5(10), 104-117.

Nigerian Stock Exchange Fact Book (2015).

Nigerian Stock Exchange (2017).

Naveed, A., Prean, N., \&Alexander, R. (2011). Introduction Arellano and Bond estimator empirical application. Retrieved on January 16, 2017 from http://homepage.univie.ac.at/robert.kunst/pan2011 pres_rabas.pdf.

Nwidobie, B. M. (2014). The random walk theory: An empirical test in the Nigerian Capital Market. Asian Economic and Financial Review, 4(12), 1840-1848.

Obayagbona, J., \& Igbinosa, S. O. (2014). Test of Random Walk Hypothesis in the Nigerian Stock Market. Current Research Journal of Social Sciences 7 (2), 27-36.

Oei, R., Ramsay, A., \& Mather, P. (2008). Earnings persistence, accruals and managerial share ownership. Accounting \& Finance, 48(3), 475-502.

Ogunwale, K. (2016, March 23). Wema bank earned \#2.3bn after tax in 2015. Daily Trust Newspaper. Retrieved on $11^{\text {th }} \quad$ April, 2017 from https://www.dailytrust.com.ng/news/business/wema-bank-earned-n2-3bn-after-tax-in2015/139071.html

Olugbenga, A. A., \& Atanda, O. A. (2014). Value relevance of financial accounting information of quoted companies in Nigeria: A trend analysis. Research Journal of Finance and Accounting, 5(8), 86-93.

Oluoch, J., \& Gichaiya, W.M. (2015). Earnings quality of public banks in Kenya: Evidence from persistence of earnings. European Scientific Journal, 11(16), 74-89.

Omokhudu, O. O., \& Ibadin, P. O. ( 2015). The value relevance of accounting information: Evidence from Nigeria. Accounting and Finance Research, 4(3), 20-30.

Onalo, U., Lizam, M., Kaseri, A., \& Usman, T. (2015). The effects of changes in accounting standards on value relevance of financial statement information of Malaysia and Nigeria banks. International Journal of Business, Economics and Management, 2(5), 135-156. 
Oyerinde, D. T. (2011). Value relevance of accounting information in the Nigerian stock market. Unpublished Ph.D Thesis, Covenant University, Ota, Nigeria.

Oyerogba, E. O. (2014). The use of voluntary disclosure in determining the quality of financial statements: Evidence from listed companies. Serbian Journal of Management, 9(2), 263280.

Oyetunji, A. (2016, October 11). Seven banks are undercapitalized, says report. Punch Newspaper. Retrieved on $11^{\text {th }}$ April, 2017 fromhttp://punchng.com/seven-banks-undercapitalised-saysreport/

Pandey, I. M. (2004). Financial management ( $9^{\text {th }}$ ed.). New Delhi: Vikas Publishing House PVT Ltd.

Papanastasopoulos, G. A. (2015). Accruals, growth, accounting distortions and stock returns: The case of FRS3 in the UK. The North American Journal of Economics and Finance, 33, 39-54.

Park, S. \& Shin, H.(2015). Earnings persistence over the macroeconomic cycle: Evidence from Korea. The Journal of Applied Business Research, 31(6), 2147-2166.

Pimentel, R. C. \& De Aguuiar, A. B. (2016). The role of earnings persistence in Valuation Accuracy and the time Horizon. Revista de Administracao de Empresas, 56(1), 71-86.

Richardson, S. A., Sloan, R. G., Soliman, M. T., \& Tuna, I. (2005). Accrual reliability, earnings persistence and stock prices. Journal of Accounting and Economics, 39, 437-485

Ruch, G. W. \& Taylor, G. (2015). Accounting conservatism: A review of literature. Journal of Accounting Literature,1-50.

Sloan, R. G. (1996). Do stock prices fully reflect information in accruals and cash flows about future earnings. The Accounting Review, 71(3), 289-315.

Sun, J., Cahan, S. F., \& Emanuel, D. (2011). How would the mandatory adoption of IFRS affect the earnings quality of US firms? Evidence from cross-listed firms in the US. Accounting Horizons, 25(4), 837-860.

Umoren, A. O., \& Enang, E. R. (2015). IFRS adoption and value relevance of financial statements of Nigerian listed banks. International Journal of Finance and Accounting, 4(1), 1-7.

Union bank records marginal profit rise for 2016. (2017, April 3). This Day Newspaper. Retrieved on $12^{\text {th }}$ April, 2017 from https://www.thisdaylive.com/index.php/2017/04/03/union-bankrecords-marginal-profits-rise-for-2016/

Uwalomwa, U., Olowe, O., \& Agu, G. (2012). An assessment of the determinants of share price in Nigeria: A study of selected listed firms. Acta Universitatis Danubius, 8(2), 78-88.

Watts, R. L. \& Leftwich, R. W. (1977). The time series of annual accounting earnings. Journal of Accounting Research, 15(2), 253-271.

Ye, K., Zhang, R., \& Rezaee, Z. (2010). Does top executive gender diversity affect earnings quality? A large sample analysis of Chinese listed firms. Advances in Accounting, 26(1), 47-54. 